\section{AUTHORS:}

Tiisetso E. Lephoto' ${ }^{1}$ Vincent M. Gray ${ }^{1}$

\section{AFFILIATION:}

'Department of Microbiology and Biotechnology, University of the Witwatersrand, Johannesburg, South Africa

\section{CORRESPONDENCE TO:}

Tiisetso Lephoto

\section{EMAIL:}

tiiseletso@yahoo.com

\section{DATES:}

Received: 31 Jan. 2019

Revised: 21 May 2019

Accepted: 26 Aug. 2019

Published: 27 Nov. 2019

\section{HOW TO CITE:}

Lephoto TE, Gray VM. First report of the isolation of entomopathogenic nematode Steinernema australe (Rhabditida: Steinernematidae) from South Africa. S Afr J Sci. 2019;115(11/12), Art. \#6008 5 pages. https://doi.org/10.17159/ sajs.2019/6008

\section{ARTICLE INCLUDES:}

$\triangle$ Peer review

$\square$ Supplementary material

\section{DATA AVAILABILITY:}

囚 Open data set

$\square$ All data included

$\square$ On request from author(s)

$\square$ Not available

$\square$ Not applicable

EDITOR:

Priscilla Baker (ID

KEYWORDS:

strain, morphological variations, survey, biocontrol agent

\section{FUNDING:}

National Research Foundation (South Africa), Gauteng Department of Agriculture and Rural Development, University of the Witwatersrand

\title{
First report of the isolation of entomopathogenic nematode Steinernema australe (Rhabditida: Steinernematidae) from South Africa
}

\begin{abstract}
A survey was conducted in Walkerville, south of Johannesburg (Gauteng, South Africa) between 2012 and 2016 to ascertain the diversity of entomopathogenic nematodes in the area. Entomopathogenic nematodes are soil-dwelling microscopic worms with the ability to infect and kill insects, and thus serve as eco-friendly control agents for problem insects in agriculture. Steinernematids were recovered in 1 out of 80 soil samples from uncultivated grassland; soil was characterised as loamy. The entomopathogenic nematodes were identified using molecular and morphological techniques. The isolate was identified as Steinernema australe. This report is the first of Steinernema australe in South Africa. S. australe was first isolated worldwide from a soil sample obtained from the beach on Isla Magdalena - an island in the Pacific Ocean, $2 \mathrm{~km}$ from mainland Chile.

\section{Significance:}

- Entomopathogenic nematodes are only parasitic to insects and are therefore important in agriculture as they can serve as eco-friendly biopesticides to control problem insects without effects on the environment, humans and other animals, unlike chemical pesticides.
\end{abstract}

\section{Introduction}

Entomopathogenic nematodes are one of the most studied microscopic species of nematodes because of their potential to act as biological control agents..$^{1,2}$ Entomopathogenic nematodes are soil-dwelling obligate parasites of insects and have a symbiotic association with insect pathogenic bacteria. ${ }^{3}$ Three genera of entomopathogenic nematodes have been identified thus far: Heterorhabditis, Steinernema and Oscheius, which are symbiotically associated with the insect pathogenic bacteria Photorhabdus, Xenorhabdus and Serratia, respectively.4-6 Entomopathogenic nematodes are found in a variety of soil habitats and demonstrate considerable differences in terms of host range, infectivity, symptomatology, reproduction, distribution and conditions for survival. ${ }^{7,8}$

Entomopathogenic nematodes have been successfully applied as effective biological control agents against some significant lepidopteran, dipteran and coleopteran insects of commercial crops. ${ }^{9}$ The effectiveness of entomopathogenic nematodes depends on both the nematodes' capability to locate, recognise and invade a host, and the virulence of the bacteria to susceptible hosts. ${ }^{9}$

Entomopathogenic nematodes infect vulnerable insect hosts while in the free-living, non-feeding infective juvenile arrested developmental stage. Once in the gut of the host, they regurgitate or release their associated pathogenic bacteria into the haemocoel, resulting in septicaemia or toxaemia in the host within $24-48 \mathrm{~h} .{ }^{4}$ Upon infection, Steinernema infective juveniles develop into either feeding males or amphimictic females. ${ }^{10}$ The infective juveniles use the invaded insect cadaver as a source of nutrition and proliferate inside the insect host for 2-3 generations. ${ }^{11}$ Once the entomopathogenic nematodes have depleted their resources, third-stage infective juveniles are produced and emerge from the cadaver, and remain in the soil while searching for a new host to infect (Figure 1). ${ }^{8,12}$

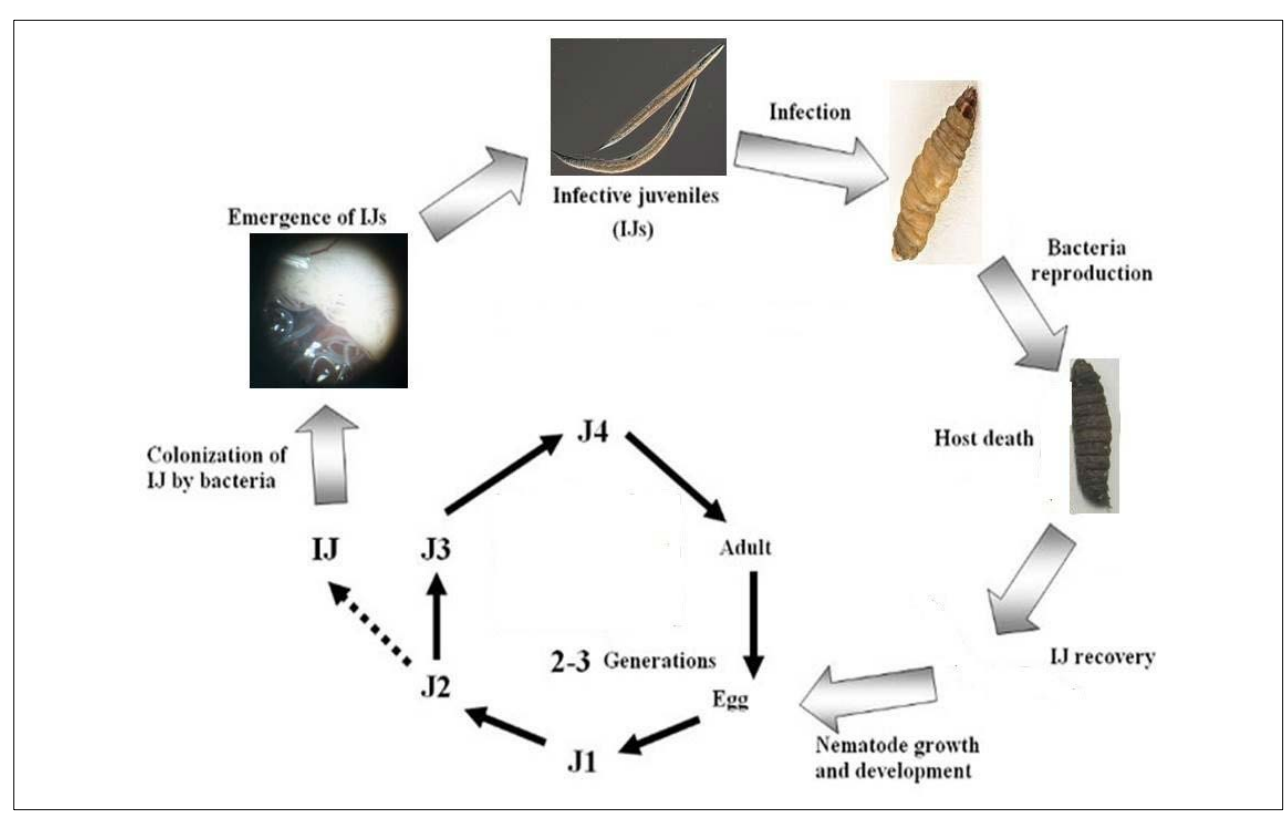

Figure 1: Life cycle of entomopathogenic nematodes 
With respect to ecological compatibility, the selection of specific species of entomopathogenic nematodes to be applied as biological controls depends on their geographical distribution patterns. ${ }^{13}$ Many species of entomopathogenic nematodes are cosmopolitan in distribution and have been isolated from a diversity of edaphic habitats throughout the world and are able to survive under a range of environmental and climatic conditions. ${ }^{14}$ Thus locally adapted species or isolates from native habitats need to be identified and their unique characteristics documented in order to evaluate their suitability as effective biological control agents against problematic insect pests within specific biogeographical regions. We aimed to isolate and identify entomopathogenic nematodes from South Africa to determine which, if any, nematodes were available in the area for potential use as biological control agents for insect pest control.

\section{Material and methods}

\section{Soil sampling}

Samples of soils with a sandy loam texture were collected from uncultivated grasslands near Walkerville, south of Johannesburg in the Gauteng Province of South Africa over a period extending from 2012 to 2016. Soil sampling was done during both autumn and winter months from various habitats and site locations. A total of 80 soil samples, comprising approximately $2 \mathrm{~kg}$ of soil, were kept in separate plastic containers and stored at $22-25{ }^{\circ} \mathrm{C}$ during transport to the laboratory. Sampling details and results are indicated in Table 1. A hand shovel was used to collect the soil in accordance with Kaya and Stock ${ }^{15}$; soil was collected to a depth of $15 \mathrm{~cm} .{ }^{11}$ Water was added to soil samples to give a moisture content not greater than $8 \%$ and the samples were then stored at room temperature overnight. ${ }^{15}$ Soil samples were then baited with Galleria mellonella (Lepidoptera: Phyralidae), the greater wax moth. ${ }^{16} \mathrm{~A}$ total of 10 Galleria larvae were placed on top of each container of soil and the container was inverted and then stored in an incubator at $25^{\circ} \mathrm{C}$. Observations were done daily to monitor for infected and dead larvae. The signs of infection in dead larvae were recorded and used for diagnosis of entomopathogenic nematode induced infection.

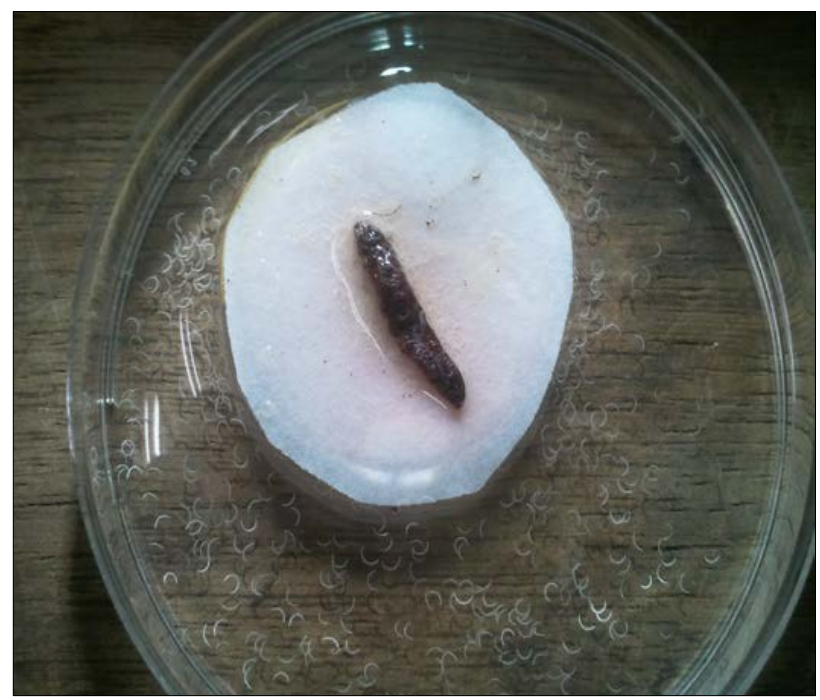

Figure 2: White trap showing infective juveniles emerging from the insect cadaver.

\section{Collection of nematodes}

Dead larvae were collected after 48-72 $\mathrm{h}$ and kept at room temperature on White traps to await the emergence of nematodes. Modified White traps as described by Kaya and Stock ${ }^{15}$ were used for the isolation of infective juveniles from dead larvae suspected to be infected with entomopathogenic nematodes. White traps were placed on a bench at room temperature during warm summer days and, during cold winter days, a heater was used to keep the room temperature at $25^{\circ} \mathrm{C}$. Emergence of infective juveniles from infected cadavers into the water (Figure 2) was greatly favoured by room temperatures of $25-30^{\circ} \mathrm{C}$. Precautions were taken to ensure that the Whatman filter paper disc was not too moist so as to introduce excess water into the insect cadaver whilst on the trap, which would lead to the death of entomopathogenic nematodes before they could emerge. Surface-sterilised nematodes taken from White traps were used for molecular ${ }^{17}$ and morphological identification ${ }^{18}$

\section{Morphological identification}

A total of 20 nematodes of first-generation males and infective juveniles were fixed with 3-4 mL of $100{ }^{\circ} \mathrm{C}$ triethanolamine formaldehyde (TAF) and left for $24 \mathrm{~h}$. TAF was then replaced with double-strength TAF and the nematodes were stored at $4^{\circ} \mathrm{C}$ to relax them for up to $1 \mathrm{~h}$, whereafter $65{ }^{\circ} \mathrm{C}$ TAF was added and the fixative was allowed to infiltrate for at least $24 \mathrm{~h}$. Fixed nematodes were transferred to a Petri dish containing $0.5 \mathrm{~mL}$ Seinhorst I solution (20 parts 95\% ethanol, 1 part glycerine and 79 parts water). A volume of $5 \mathrm{~mL}$ of $95 \%$ ethanol was placed into the watch glass containing the nematodes and the watch glass was placed in the desiccator. The desiccator was placed in an oven preheated to $35^{\circ} \mathrm{C}$ for $12 \mathrm{~h}$. The watch glass with nematodes was then removed from the desiccator, filled with Seinhorst II solution (95 parts 95\% ethanol, 5 parts glycerine) and placed in a glass Petri dish. The Petri dish was left partially open to allow for slow ethanol evaporation. The Petri dish containing the watch glass was placed in an oven preheated to $40^{\circ} \mathrm{C}$ for $3 \mathrm{~h}$. Nematodes were then mounted on glass slides carefully to avoid crushing them before analysis under the microscope. Morphological analysis was done using an Olympus microscope at different magnifications. Morphometric measurements of the nematodes are presented in Table 2.

\section{Molecular identification}

The following primers were used for molecular identification: TW81 (F) 5'-GCGGATCCGTTTCCGTAGGTGAACCTGC-3'; AB28 (R) 5'-GCGGATCCATATGCTTAAGTTCAGCGGGT-3'. A polymerase chain reaction (PCR) was done using $25 \mu \mathrm{L}$ PCR master mix, $22 \mu \mathrm{L}$ nucleasefree water, $1 \mu \mathrm{L}$ forward primer TW81, $1 \mu \mathrm{L}$ reverse primer AB28 and $1 \mu \mathrm{L}$ DNA (ng). Total reaction volume was $50 \mu \mathrm{L}$. Samples were mixed gently and placed under the following conditions to amplify the internal transcribed spacer (ITS) region found between the $18 \mathrm{~S}$ and $28 \mathrm{~S}$ rDNA: (1) initial denaturation before cycling: $94{ }^{\circ} \mathrm{C}$ for $5 \mathrm{~min} ; 25$ cycle amplification series; (2) denaturation at $95^{\circ} \mathrm{C}$ for $60 \mathrm{~s}$; (3) annealing at $64{ }^{\circ} \mathrm{C}$ for $60 \mathrm{~s}$; (4) extension at $72{ }^{\circ} \mathrm{C}$ for $120 \mathrm{~s}$; and (5) final extension after cycling: $72^{\circ} \mathrm{C}$ for $10 \mathrm{~min}$.

A $0.5 \%$ agarose gel was prepared in order to confirm the presence and quality of the extracted DNA. An amount of $0.25 \mathrm{~g}$ of agarose power was dissolved in $50 \mathrm{~mL}$ of $1 \times$ TBE (Tris-borate-EDTA) buffer and $1 \mu \mathrm{L}$ of ethidium bromide was added and the contents mixed gently. The gel was left to solidify with the well comb inserted. For each $10 \mu \mathrm{L}$ sample, only $5 \mu \mathrm{L}$ of the samples were loaded into the wells and separated on

Table 1: Locality, habitat and date of sampling and soil characteristics of samples

\begin{tabular}{|c|c|c|c|c|c|c|}
\hline \multicolumn{5}{|c|}{ Sampling } & \multicolumn{2}{|c|}{ Soil characteristics } \\
\hline Location & Coordinates: Positive site & Coordinates: Negative sites & Sampling dates & Habitat & Soil type & $\mathrm{pH}$ \\
\hline Walkerville, South Africa & $\begin{array}{l}26^{\circ} 28^{\prime} 12.1^{\prime \prime S} \\
27^{\circ} 56^{\prime} 33.0^{\prime \prime} \mathrm{E}\end{array}$ & $\begin{array}{c}26^{\circ} 28^{\prime} 12.8^{\prime \prime} \mathrm{S} \\
27^{\circ} 56^{\prime} 33.2 " \mathrm{E} \\
\text { and } \\
26^{\circ} 28^{\prime} 12.1^{\prime \prime} \mathrm{S} \\
27^{\circ} 56^{\prime} 32.8^{\prime} \mathrm{E}\end{array}$ & $\begin{array}{c}\text { May } 2012 \\
\text { August } 2016\end{array}$ & Uncultivated grassland & Sandy loam & 6.1 \\
\hline
\end{tabular}


the gel for 30 min at $90 \mathrm{~V}$ immersed in $1 \times$ TBE with constant current. A $2 \%$ agarose gel with ethidium bromide was used for visualisation of the DNA (Figure 3).

Successful PCR products were sent to Inqaba Biotechnical Industries (Pty) Ltd (Pretoria, South Africa) for sequencing. The nucleotide sequence alignment website (BLAST) of the US National Center for Biotechnology Information (NCBI) was used to identify the unknown species of nematodes. Phylogenetic analysis was done using sequences obtained from the NCBI's GenBank database. Sequences were aligned using MUSCLE on MEGA6 before generating phylogenetic trees. ${ }^{19}$ The maximum-likelihood method based on the Tamura-Nei model was used to construct the trees.

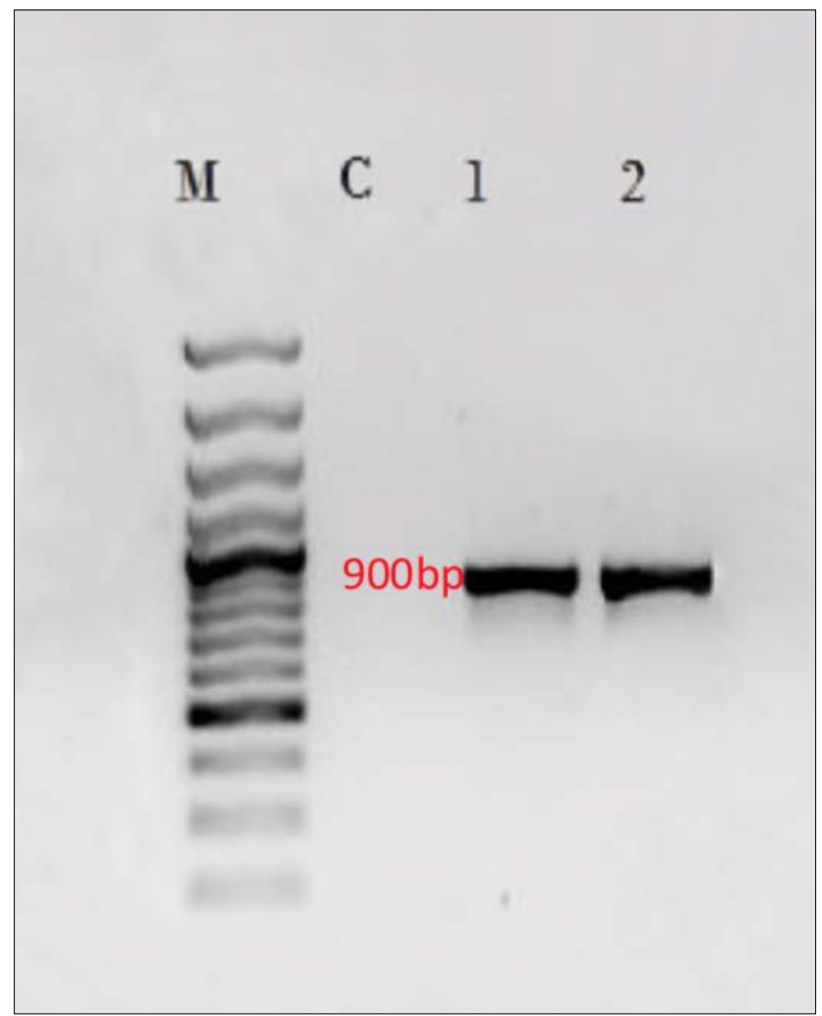

M, 100 bp plus molecular weight marker; C, control lane (no DNA); 1, unknown; 2 , replicate of unknown

Figure 3: $18 \mathrm{~S}$ rDNA internal transcribed spacer (ITS) region PCR products resolved on a $2 \%$ agarose gel.

\section{Animal handling}

All relevant national regulations and institutional policies on the care and use of invertebrates in research were complied with.

\section{Results}

Steinernematids were recovered in 1 out of $80(1.25 \%)$ soil samples obtained from uncultivated grassland in Walkerville, south of Johannesburg, South Africa. The soil positive for steinernematids was classified as sandy loam.

Morphometric analysis showed that the isolates obtained from infective juvenile and male nematodes belonged to the family Steinernematidae; the isolate (TEL) is conspecific with Steinernema austra/e. ${ }^{20}$ Compared to that previously described for $S$. australe, the infective juveniles of TEL appear smaller in all measured characteristics - body length, tail length and pharynx length. $S$. australe TEL is characterised by the length of the male $(1598 \mu \mathrm{m})$, which is slightly shorter than that previously described for S. australe, ${ }^{20}$ which have a total body length of $(1606 \mu \mathrm{m})$. The total body length of infective juveniles of $S$. australe TEL is $1301 \mu \mathrm{m}$, which is close to that of $S$. australe with a total body length of $1316 \mu \mathrm{m}$. S. australe TEL male spicule length is $70 \mu \mathrm{m}$ and resembles $S$. australe spicule length of $72 \mu \mathrm{m}$. The $S$. australe TEL pharynx length is slightly smaller (181 $\mu \mathrm{m})$ than the pharynx length of $S$. australe $(186 \mu \mathrm{m})$. The male tail length of S. australe TEL is $27 \mu \mathrm{m}$, which approximates that of $S$. australe which has a tail length of $29 \mu \mathrm{m}$.

Table 2: Comparative morphometric data of Steinernema australe (South African isolate and 167 known species ${ }^{20}$ )

\begin{tabular}{l|l|l}
\hline \hline & \multicolumn{1}{|c|}{ S. australe TEL } & \multicolumn{1}{c}{\begin{tabular}{c}
\multicolumn{1}{c}{ S. australe } \\
$(\boldsymbol{n}=167$
\end{tabular}} \\
\hline \hline Body length & \multicolumn{1}{|c}{$1598 \pm 30.9 .(1382-1899)$} & $1606 \pm 31.8(1401-1937)$ \\
\hline Tail length & $27 \pm 0.8(19-32)$ & $29 \pm 0.9(20-35)$ \\
\hline Spicule length & $70 \pm 1.1(52-74)$ & $72 \pm 1.2(55-78)$ \\
\hline Pharynx length & $181 \pm 2.3(158-198)$ & $186 \pm 2.4(167-205)$ \\
\hline D\% & $68 \pm 1.2(57-83)$ & $71 \pm 1.3(59-87)$ \\
\hline E\% & - & - \\
\hline MUC & - & - \\
\hline \hline & \multicolumn{1}{|c}{ Infective juveniles } \\
\hline \hline Body length & $1301 \pm 20.9(1155-1480)$ & $1316 \pm 21.4(1162-1484)$ \\
\hline Tail length & $99 \pm 1.4(90-111)$ & $103 \pm 1.6(92-114)$ \\
\hline Spicule length & - & - \\
\hline Pharynx length & $163 \pm 2.7(138-189)$ & $169 \pm 2.9(140-194)$ \\
\hline D\% & $62 \pm 1.1(56-74)$ & $65 \pm 1.3(57-78)$ \\
\hline E\% & $104 \pm 1.8(91-119)$ & $107 \pm 1.8(94-122)$ \\
\hline MUC & - & - \\
\hline
\end{tabular}

All measurements represent mean and range in $\mu \mathrm{m}$.
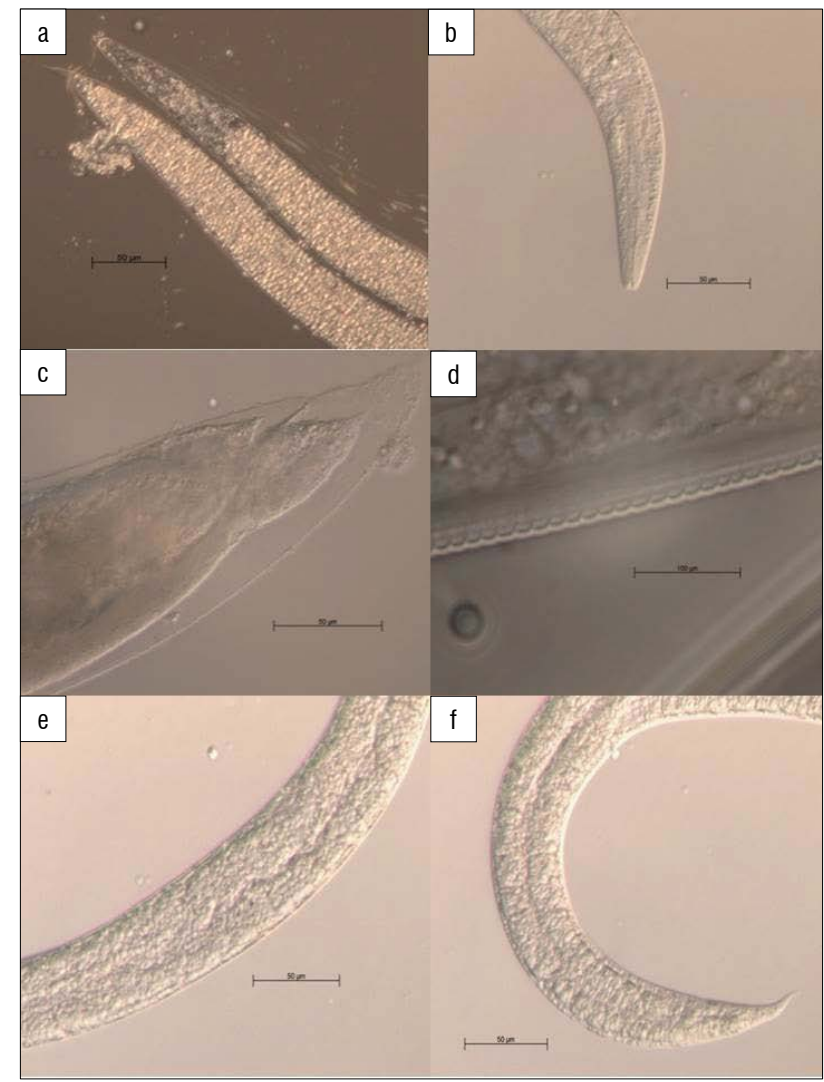

Figure 4: Steinernema australe: (a) male and female adult nematodes, (b) the head, highlighting the mouth, stylet, oesophagus and metacorpus, (c) tail of a female adult, (d) thick cuticle of an adult body, (e) intestines and (f) pointed female tail. 


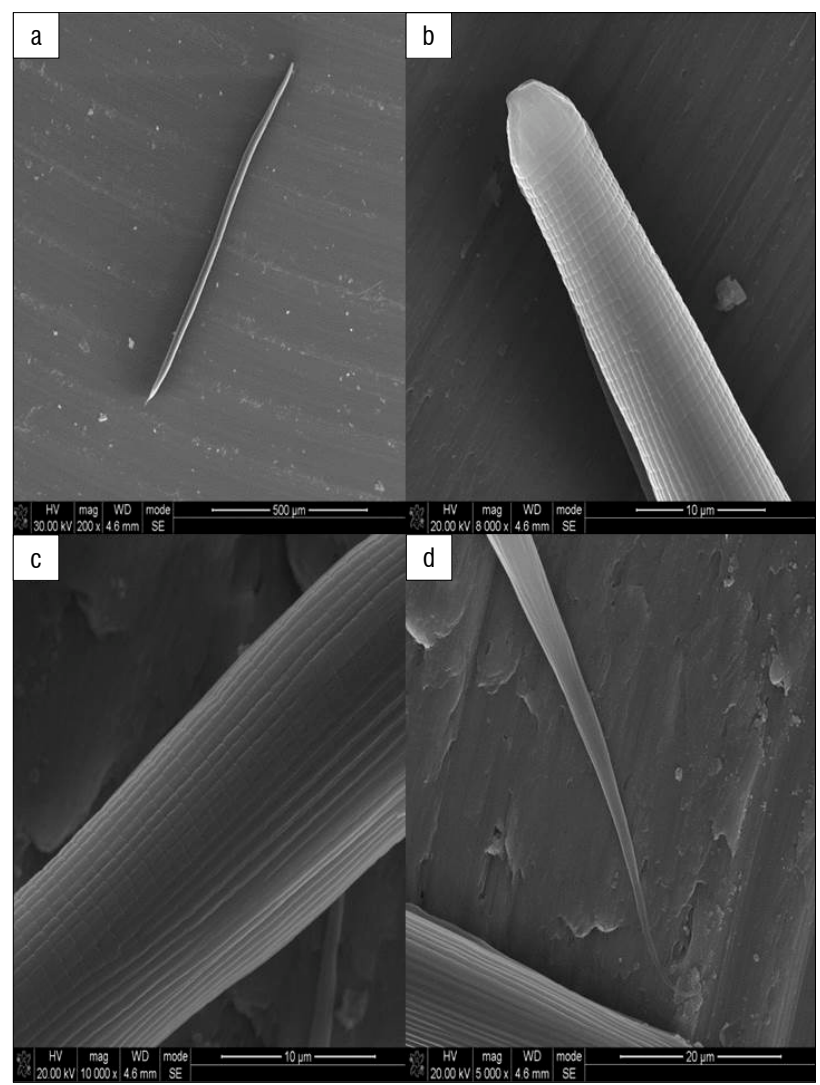

Figure 5: Scanning electron microscopy of Steinernema australe: (a) infective juveniles, (b) tessellate anterior region with the mouth and papillae, (c) radial symmetry and tessellate body and (d) pointed tail of a female.

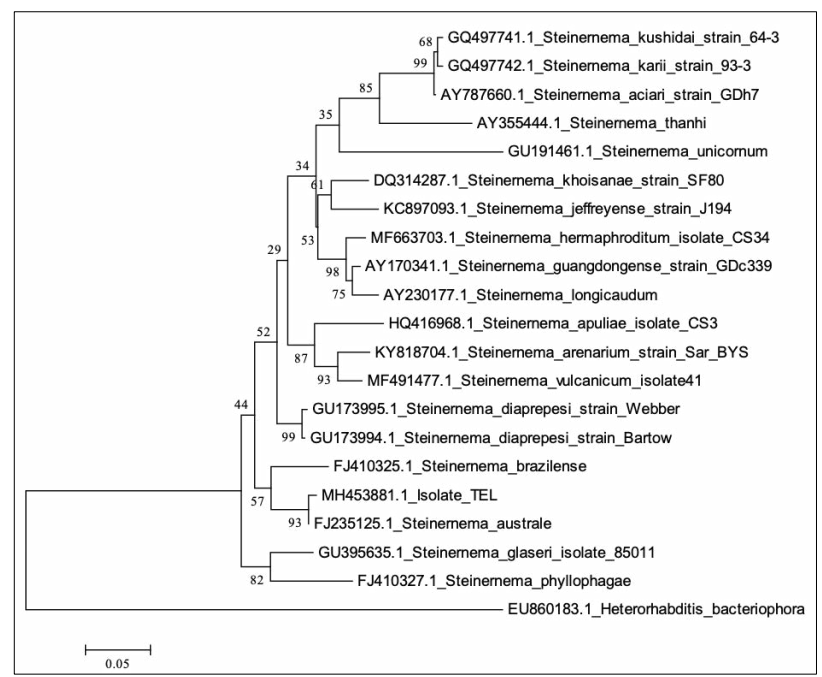

Figure 6: Evolutionary relationships of the new South African entomopathogenic nematode isolate (TEL). Sequences were aligned first using the MUSCLE alignment tool on MEGA6 software. The evolutionary history of the aligned sequences was centred on the analysis of the 18S rDNA internal transcribed spacer (ITS) region inferred using the maximum-likelihood method based on the Tamura-Nei model ${ }^{19}$ in MEGA6. The bootstrap consensus tree was inferred from 1000 replications and the tree is drawn to scale, with branch lengths measured by the number of substitutions per site (next to the branches). The bar scale of 0.05 substitutes per nucleotide position.

The morphometric data presented in Table 2 and Figures 4 and 5 are considered to be the most consistent for $S$. australe described by Adams and Nguyen ${ }^{21}$. Scanning electron microscopy provides an understanding of the surface structure of the nematodes (Figure 5).

Phylogenetic analysis of the studied isolate of $S$. australe and homologous sequence of the same genus from GenBank is presented in Figure 6. The phylogenetic tree reveals that the South African isolate is grouped with the strain $S$. australe and thus supports that the isolate identified in the study is $S$. australe. The sequences were deposited in GenBank under accession number $165 \mathrm{MH} 453881$ (TEL).

\section{Discussion}

This is the first record of a specific species from the family Steinernematidae, namely Steinernema australe, found in South Africa, thus confirming the extent of its geographical occurrence in the southern hemisphere, for comparative purposes with previous studies. The prevalence of steinernematid isolation from soil samples in our study was $2 \%$, which is similar to previous reports by Edgington et al. ${ }^{20}$ $S$. australe was recovered from uncultivated grassland only, and all positive samples were from locations in close proximity.

Soil samples were collected between autumn and winter in South Africa and recovery of entomopathogenic nematodes from the positive site suggests that the nematodes are able to survive in both seasons. S. australe was found in sandy loam soil collected from uncultivated grassland on Road Number 6 in Walkerville whereas Road Number 7 and Boundary Road were negative sites, that is, no entomopathogenic nematodes were recovered from these sites, which were one block apart.

Our survey was conducted in Gauteng which is in the north of South Africa. In previous surveys conducted in various provinces in South Africa, a novel undescribed steinernematid was recovered only from the Free State and KwaZulu-Natal Provinces where humid subtropical environments predominate and the entomopathogenic nematodes reside in soil which has a high clay content and is less acidic. ${ }^{22}$

The effectiveness of entomopathogenic nematodes as biocontrol agents is affected by the type of soil in which they reside. Soil properties such as particle size, organic matter, texture and several other traits influence their foraging abilities and dispersal. ${ }^{23}$

\section{Acknowledgements}

We thank the National Research Foundation (South Africa), Gauteng Department of Agriculture and Rural Development and the University of the Witwatersrand for funding.

\section{Authors' contributions}

T.E.L.: Collected soil samples; undertook the research, species identification, experimental work as listed in the 'Materials and methods', and data analysis; interpreted the results; and wrote the manuscript. V.M.G.: Collected soil samples and edited the manuscript.

\section{References}

1. Malan AP, Nguyen KB, Addison MF. Entomopathogenic nematodes (Steinernematidae and Heterorhabditidae) from the southwestern parts of South Africa. Afr Entomol. 2006;12:65-69.

2. Alatorre-Rosas R, Kaya HK. Interspecific competition between entomopathogenic nematodes in the genera Heterorhabditis and Steinernema for an insect host in sand. J Invertebr Pathol. 1990;55:179-188. https://doi. org/10.1016/0022-2011(90)90053-9

3. Hatting J, Stock SP, Hazir S. Diversity and distribution of entomopathogenic nematodes (Steinernematidae, Heterorhabditidae) in South Africa. J Invertebr Pathol. 2009;102:120-128. https://doi.org/10.1016/j.jip.2009.07.003

4. Adams BJ, Fodor A, Koppenhöfer HS, Stackebrandt E, Stock SP, Klein MG. Biodiversity and systematics of nematode-bacterium entomopathogens. Biol Control. 2006;37:32-49. https://doi.org/10.1016/j.biocontrol.2005.11.008

5. Alia VIK, Harma GAS, Lan DAISH, Anguly SUG. Biocontrol potential of Steinernema thermophilum and its symbiont Xenorhabdus indica against lepidopteran pests: Virulence to egg and larval stages. J Nematol. 2014;46:18-26. 
6. Zhang C, Liu J, Xu M, Sun J, Yang S, An X, et al. Heterorhabditidoides chongmingensis gen. nov., sp. nov. (Rhabditida: Rhabditidae), a novel member of the entomopathogenic nematodes. J Invertebr Pathol. 2008;98:153-168. https://doi.org/10.1016/j.jip.2008.02.011

7. Grenier E, Laumond C, Abad P. Characterization of a species-specific satellite DNA from the entomopathogenic nematode Steinernema carpocapsae. Mol Biochem Parasitol. 1995;69:93-100. https://doi.org/10.1016/01666851(94)00197-u

8. Campos-Herrera R, Barbercheck M, Hoy CW, Stock SP. Entomopathogenic nematodes as a model system for advancing the frontiers of ecology. $J$ Nematol. 2012;44:162-176.

9. Athanassiou CG, Kavallieratos NG, Menti H, Karanastasi E. Mortality of four stored product pests in stored wheat when exposed to doses of three entomopathogenic nematodes. J Econ Entomol. 2010;103(3):977-984. https://doi.org/10.1603/ec09202

10. Mráček Z, Qi-zhi L, Nguyen KB. Steinernema xueshanense n. sp. (Rhabditida, Steinernematidae), a new species of entomopathogenic nematode from the province of Yunnan, southeast Tibetan Mts., China. J Invertebr Pathol. 2009;102:69-78. https://doi.org/10.1016/j.jip.2009.05.006

11. Stuart RJ, Barbercheck ME, Grewal PS, Taylor RJ, Hoy WC. Morphological and functional dimorphism in Xenorhabdus spp., bacteria symbiotically associated with the insect pathogenic nematodes Neoaplectana and Heterorhabditis. Microbiology. 2006;121:303-309. https://doi. org/10.1099/00221287-121-2-303

12. Tarasco E, Mráček Z, Nguyen KB, Triggiani O. Steinernema ichnusae sp. $\mathrm{n}$. (Nematoda: Steinernematidae) a new entomopathogenic nematode from Sardinia Island (Italy). J Invertebr Pathol. 2008;99:173-185. https://doi. org/10.1016/j.jip.2008.05.001

13. Flint ML, Dreistadt SH. Natural enemies' handbook, the illustrated guide to biological pest control. Berkeley, CA: University of California Press; 1998. p. 2-35.

14. Shapiro-Ilan DI, Han R, Dolinksi C. Entomopathogenic nematode production and application technology. J Nematol. 2012;44:206-217.
15. Kaya HK, Stock SP. Techniques in insect nematology. In: Lacey LA, editor. Manual of techniques in insect pathology. London: Academic Press; 1997. p. 281-324. https://doi.org/10.1016/b978-012432555-5/50016-6

16. Bogus MI, Kedraa E, Bania J, Szczepanik M, Czygier M, Jablonski P, et al. Different defense strategies of Dendrolimus pini, Galleria mellonella, and Calliphora vicina against fungal infection. J Insect Physiol. 2007;53:909-922. https://doi.org/10.1016/j.jinsphys.2007.02.016

17. Powers TO, Todd TC, Burnell AM, Murray PC, Fleming CC, Szalanski AL, et al. The rDNA internal transcribed spacer region as a taxonomic marker for nematodes. J Nematol. 1997;29(4):441-450.

18. Stock SP, Kaya HK. A multivariate analysis of morphometric characters of Heterorhabditis species and the role of morphometrics in the taxonomy of the species of the genus. J Parasitol. 1996;82:806-813. https://doi. org/10.2307/3283895

19. Tamura K, Stecher G, Peterson D, Filipski A, Kumar S. MEGA6: Molecular evolutionary genetics analysis version 6.0. Mol Biol Evol. 2013;30(12):27252729. https://doi.org/10.1093/molbev/mst197

20. Edgington S, Buddie AG, Tymo L, Hunt DJ, Nguyen KB, France Al, et al. Steinernema australe n. sp. (Panagrolaimomorpha: Steinernematidae), a new entomopathogenic nematode from Isla Magdalena, Chile. Nematology. 2009;11:699-717. https://doi.org/10.1163/156854108x399326

21. Adams BJ, Nguyen KB. Taxonomy and systematics. In: Gaugler R, editor. Entomopathogenic nematology. Wallingford, UK: CAB International; 2002. p. 1-33.

22. James M, Malan AP, Addison P. Surveying and screening South African entomopathogenic nematodes for the control of the Mediterranean fruit fly, Ceratitis capitate (Wiedemann). Crop Prot. 2018;105:41-48. https://doi. org/10.1016/j.cropro.2017.11.008

23. Strauch O, Niemann I, Neumann A, Schmidt AJ, Peters A, Ehlers RU. Storage and formulation of the entomopathogenic nematodes Heterorhabditis indica and $H$. bacteriophora. BioControl. 2000;45:483-500. https://doi. org/10.1023/A:1026528727365 